\title{
O sertão formal da política brasileira de conservação da natureza
}

The sertão and the Brazilian nature conservation policy

\section{Introdução}

O que significa o termo sertão? Diversos autores têm chamado a atenção para a sua riqueza semântica. De acordo com Neves (2003), o termo é utilizado desde os primórdios coloniais e consta nos textos de doação das capitanias. Para os filólogos contemporâneos, sertão significa lugar recôndito, despovoado, distante do litoral, mas não necessariamente agreste (Neves, 2003). A palavra sertão aparece geralmente relacionada à região Nordeste do Brasil e, neste sentido, o autor afirma que o sertão tornou-se uma categoria geográfica relacionada ao semiárido, espacial (interior), econômica (pecuária) e social (região pouco povoada). Mas, além do mais conhecido - o sertão nordestino -, existem muitos outros sertões: o de Minas Gerais; de Mato Grosso; de Goiás; do extremo Oeste de Santa Catarina e da região de Sorocaba, por onde passavam os tropeiros; o sertão de dentro, no Amazonas (Amado, 1995), entre outros. Assim, conclui Neves (2003), o imaginário de sertão construído por viajantes, cronistas e missionários, mais do que oposição ao litoral, apresenta a ideia de distanciamento em relação ao poder público e a projetos modernizadores. Os centros urbanos

1 É professora adjunta do Departamento de Ciências Sociais e do Programa de Pós-Graduação em Ciências Sociais da Universidade Federal Rural do Rio de Janeiro (UFRRJ). Possui mestrado em Antropologia e Sociologia e doutorado em Sociologia pela Universidade Federal do Rio de Janeiro (UFRJ). Seus principais temas de pesquisa são: natureza, espaço e sociedade, políticas ambientais, participação e campesinato. Atualmente desenvolve trabalhos relacionados a dinâmicas territoriais, conflitos ambientais, participação em conselhos, redes sociotécnicas e sistemas agroalimentares. E-mail:<annelisecff@yahoo.com.br>. 
e os sertões configurariam, deste modo, espaços simbólicos explicativos da dicotomia da sociedade brasileira.

O discurso da sertanidade (Sarmento, 1998) e da associação de uma autoimagem e do pertencimento nacional-brasileiro (Alves, 2004) ganha expressão a partir da obra fundadora de Euclides da Cunha, Os Sertões, publicada em 1902. A partir desta obra, inaugura-se, de acordo com Sarmento (1998, p. 4), uma construção discursiva do sertão, que, informada pela lógica da obra euclidiana, é fruto de um diálogo de textos que produzem variações de interpretações sobre o tema. Sertão como patologia, retratado pela utopia higienista, sertão como lócus de uma cultura de folk, em contraste com a civilização, como dicotomia campo/cidade. Lima (1999; 2009) destaca como o debate a respeito do litoral e do sertão expressa uma representação geográfica da identidade nacional e a valorização positiva ou negativa do sertão pode ser comparada, como em outros países, ao dilema de um processo civilizatório visto como inevitável e outro com possibilidade de alguma escolha.

"Neste sentido", conclui Sarmento (2009), “O Sertão Carioca, escrito em 1933, é uma construção específica da representação do modelo de sertão pós-Euclides". Seu autor, o naturalista autodidata Armando Magalhães Corrêa, retrata um quadro de mudanças sociais e a possibilidade de escolha de um caminho autóctone de desenvolvimento para o país, inspirado no "Brasil real" (Lima, 2009, p. 107). O livro descreve, com tom engajado, como, a poucos quilômetros da capital do país - Rio de Janeiro ${ }^{2}$-, existe uma realidade social marcada pelo abandono, pela ausência de saneamento, de educação e de um projeto de desenvolvimento.

Ao retratar as dificuldades enfrentadas por essa população, carente de saneamento, educação e assistência médica, que muitas vezes degradava a natureza devido à precariedade de suas condições de vida, o livro trazia como proposta transformar os sertanejos em verdadeiros protetores do seu ambiente, desde que recebessem a devida assistência do Estado (Franco e Drummond, 2005). Apesar

2 Em 20 de abril de 1960, a capital do país é transferida do Rio de Janeiro para Brasília. 
de defender a necessidade de uma intervenção civilizatória sobre o sertão, Corrêa alertava sobre o risco dos efeitos nefastos do contato com o mundo urbano e a destruição das características desta população, detentora de uma brasilidade autêntica.

É muito provável que a zona rural carioca também fosse referida desde longa data como sertão, mas, a partir da obra de Corrêa, esse título é celebrizado, fazendo com que sobre ela recaísse um conjunto de significados que passaram a adjetivar esse rural em contraste com as áreas mais urbanizadas da cidade. Desse modo, a descrição da zona rural do Rio de Janeiro como Sertão Carioca, mais do que simplesmente referir-se a ela de forma corriqueira como uma área rural ou interiorana, agregava um universo semântico sobre a dicotomia campo/cidade, litoral/sertão, e buscava, assim, compreender as especificidades dos contingentes populacionais mais afastados dos núcleos civilizados do país, incorporando-os à nação.

Com surpreendente atualidade, O Sertão Carioca abriga questionamentos pertinentes à temática socioambiental, à medida que propõe um modelo de desenvolvimento para o país, que integra a preservação da natureza e a melhoria das condições de vida dos autênticos brasileiros representados pelos sertanejos. A proposta de criação de parques era vista pelo autor como elemento importante em seu projeto de desenvolvimento dos sertões, integrando desenvolvimento social rural com o cuidado da natureza.

Curiosamente, em 1974, uma parcela significativa do Sertão Carioca foi transformada em Parque Estadual da Pedra Branca (PEPB). Ocorre que a legislação que define as Unidades de Conservação (UCs) ${ }^{3}$ de proteção integral, como são os parques, determina que esses espaços devem ser destinados apenas à vida silvestre,

3 Área protegida é uma categoria abrangente que inclui tanto parques, reservas e florestas quanto Áreas de Proteção Permanente (APPs), reservas legais etc., sendo citada em diversas leis orgânicas e no Código Florestal. A partir do ano 2000, com a criação da Lei no 9.985 - Sistema Nacional de Unidades de Conservação (SNUC), o termo Unidade de Conservação (UC) passou a definir tipos específicos de áreas protegidas divididos em duas categorias: de proteção integral (de uso indireto), tais como parques, reservas biológicas; e de uso direto, tais como Reservas de Desenvolvimento Sustentável (RDS) e Reservas Extrativistas (Resex). Como tratamos no texto de processos de longa duração e, portanto, anteriores à criação do SNUC, utilizamos o termo área protegida ou UC em relação aos parques de acordo com o contexto explicativo. 
inviabilizando a permanência humana. Nesses termos, cabe perguntar: o que diria Corrêa se soubesse que seu Sertão Carioca, com sua gente e seu modo de vida rústico, sobreviveu justamente em um parque? (Fernandez, 2009; 2010; 2014).

O território a ser protegido não se consolidou como "espaço intocado" das espécies naturais, "os sertanejos" tampouco foram incorporados a um projeto civilizatório que lhes garantisse melhores condições de vida e, de alguma forma, preservou-se sua autenticidade cultural.

Contudo, não se trata de uma contradição exclusiva do PEPB. Quando se observa o histórico de criação de áreas protegidas de proteção integral no Brasil, sobretudo as do tipo parque, desde a década de 1930, constata-se que a maioria acumula conflitos de permanência humana em seus territórios e que sua existência tem imposto restrições severas a grupos que historicamente desenvolveram relações de forte interação com a natureza e cuja subsistência depende da utilização direta dos recursos naturais.

Ao contrário do que o autor poderia prever, a política de criação de áreas protegidas no Brasil não esteve integrada a um projeto de nação rumo aos campos, mas foi criada em zonas intersticiais e como medida compensatória de grandes projetos de desenvolvimento (Barreto Filho, 2004). São, em geral, áreas menos valorizadas - áreas montanhosas, várzeas, de matas secundárias -, justamente ocupadas por populações que Corrêa definiria como sertanejos: populações caiçaras, caboclas, descendentes de etnias indígenas, remanescentes de quilombolas etc., criando uma situação paradoxal: tais grupos, ao mesmo tempo em que passaram a sofrer restrições pela imposição da legislação ambiental, puderam se defender de formas diversas da expropriação de seus territórios - urbanização, grilagem de terras, expansão de atividades agropecuária etc. - por estarem em áreas protegidas.

Assim, à revelia do que conceberam os primeiros ideólogos da conservação, combinou-se o não uso da natureza ${ }^{4}$ em espaços prote-

4 Ainda que esse ideal não se realize de forma plena, devido às contradições sociais anteriormente apresentadas. 
gidos com o uso sem limites fora desses espaços. Observa-se que justamente no contexto das políticas do nacional-desenvolvimentismo, dos anos de 1950 até meados de 1980, que a criação de parques teve maior dinamismo. Nas palavras de Teresa Urban (1998, p. 108), "foram anos de chumbo e de ouro para a conservação da natureza no Brasil".

Fazendo uso da expressão utilizada por Sarmento (1998), pretende-se aqui recriar um sertão formal, à medida que se inspirar no processo de constituição do PEPB e nas reflexões de Armando Magalhães Corrêa leva-nos também a pensar sobre muitos outros sertões transformados em parques e as contradições produzidas pela política brasileira de conservação da natureza. Pretende-se mostrar que o embate entre duas correntes ambientais - o conservacionismo e o socioambientalismo -, conformadas ao longo de diferentes conjunturas políticas e jurídico-institucionais, reproduzem no campo ambiental os dilemas sobre os rumos do projeto civilizacional brasileiro.

\section{Preservacionismo e conservacionismo em contraste com novas orientações ambientais}

É comum identificar a noção de preservação em oposição à noção de conservação nos debates ambientais. A primeira é definida pela ideia de proteção e, portanto, de não utilização dos recursos naturais, enquanto a segunda pressupõe o uso equilibrado e racional dos elementos da natureza.

A polarização entre esses dois princípios ganha força no século XIX, nos Estados Unidos, a partir das reflexões do engenheiro florestal Gifford Pinchot, que acreditava na conservação a partir do uso equilibrado dos recursos naturais, antecipando o que mais tarde seria chamado de desenvolvimento sustentável; e a segunda, inspirada nas ideias de Thoreau, Marsh e, posteriormente, John Muir, defendia a igualdade de direitos entre homens e animais. Os princípios defendidos por Muir e outros preservacionistas foram determinantes para a consagração de um modelo de proteção baseado em parques nacionais, já que, ao defenderem a igualdade entre os 
seres vivos, concebiam a necessidade de espaços protegidos, em que os homens poderiam apenas usufruir indiretamente da natureza, reservando-os primordialmente para a manutenção da vida de outras espécies (Diegues, 2002; Fernandez, 2009; 2014).

$\mathrm{Na}$ atualidade, ambas as definições tomadas uma frente à outra são contrastivas e ainda possuem eficácia explicativa. ${ }^{5}$ No entanto, é necessário considerar o contexto em que são utilizadas, os atores que dela fazem uso e as disputas em questão. Considerando a historicidade desses termos, partilhamos com Lago e Pádua (1984) o entendimento de que o termo conservação da natureza incorporou e alargou os sentidos atribuídos à ideia de preservação. Franco e Drummond (2009, p. 49), neste sentido, defendem que, no Brasil, entre os anos de 1920 a 1940, essas duas correntes foram absorvidas de forma articulada e que os conceitos de proteção, conservação e preservação eram intercambiáveis, já que havia, entre os pensadores dessa geração, orientações voltadas tanto para o uso equilibrado dos recursos naturais quanto para a preservação da natureza, integrando um só projeto de construção nacional.

No cenário internacional houve também uma progressiva adaptação de sentidos entre os dois termos. Assim, a International Union for Preservation of Nature (IUPN) fundada em 1948, organização protagonista no desenvolvimento do conceito mundial de áreas protegidas, ${ }^{6}$ em 1956 alterou o nome da entidade para International Union for Conservation of Nature (UICN). A substituição do termo proteção por conservação indicou o crescente fortalecimento deste último na definição do conceito de áreas protegidas. ${ }^{7}$ No âmbito da

5 Por exemplo, nos planos de manejo de UCs de proteção integral, como são os parques, algumas áreas podem ser definidas como áreas de preservação (ou seja, não disponíveis à visitação) e outras de conservação da natureza, que admitem algumas formas de manejo.

6 A IUCN tinha a proposta de auxílio e assessoria aos diversos países no planejamento e manejo dessas áreas (Simon, 2003, p. 59).

7 Embora o "mito da natureza intocada" (Diegues, 2002) seja o componente mais forte do imaginário social vinculado aos parques e stricto sensu associado à ideia de preservação, o uso público exige o manejo permanente desses espaços, com a instalação de uma série de equipamentos, trilhas, centros de visitação, áreas de lazer, justificando o termo mais abrangente conservação. Do mesmo modo, a constatação de que havia exceções no uso desses espaços (atividades agrícolas, pecuária, caça, moradias) inaugura o debate sobre zoneamento na I Conferência Mundial sobre Parques Nacionais em Seattle, no ano de 1962 (Barreto Filho, 2006). 
UICN foi criada, em 1960, a Comissão Mundial de Parques Nacionais, que organizou diversas assembleias e congressos para discutir a temática dos parques nacionais em todo o mundo.

De acordo com Lago e Pádua (1984), o surgimento de diversas correntes ecológicas formadas a partir da confluência entre movimentos sociais de contracultura, marxistas, anarquistas, entre outros, contribuiu para o estabelecimento de uma distinção entre ecologistas e conservacionistas. Segundo os autores (1984, p. 35), os conservacionistas passaram a ser definidos como aqueles que têm como foco essencial de suas atividades a conservação de áreas naturais, não se envolvendo diretamente em temas que não dizem respeito a essa questão.

Ao longo do texto, demonstraremos como, no caso brasileiro, essa perspectiva confirma-se, não exatamente pela determinação exclusiva de seus protagonistas, mas pela estrutura de oportunidades políticas com as quais se depararam e puderam atuar, sobretudo a partir da década de 1940.

Adotamos, deste modo, o termo conservacionismo em contraste com outras correntes emergentes que aqui definimos como ecologia política e socioambientalismo. ${ }^{8}$ A primeira ganha força na década de 1970 e reúne diversos movimentos que partilhavam de uma leitura crítica e de contestação em relação à sociedade moderna, ao capitalismo e às contradições e injustiças sociais a partir da apropriação desigual da natureza. Já a segunda é tida como uma invenção brasileira e surge na Amazônia, na década de 1980. A luta dos seringueiros pela conquista de terras que permitissem manter

8 Defendemos que conservacionismo e socioambientalismo são termos cunhados nos debates específicos sobre áreas protegidas no Brasil, embora possam ter seus sentidos e usos alargados na atualidade. Nessa perspectiva, discordamos da terminologia (mas não da reconstituição desses movimentos) de Alonso, Costa e Maciel (2007), que adotam o termo socioambientalismo em referência aos diversos movimentos ambientalistas nacionais que ganham expressão na década de 1970, com agendas humanistas e de crítica ao estilo de vida urbano-industrial. Os autores, ao descreverem uma nova estrutura de oportunidades políticas trazidas pela Rio-92, apontam a convergência de temáticas conservacionistas com a agenda social, definindo-as como neoconservacionismo. Acreditamos ser mais preciso falar em referência a estes movimentos ambientais orientados por uma agenda marrom, como ecologia política, mesmo por se tratar de uma categoria nativa (Pádua, 1987), e que, a partir da década de 1990, também se interessam pelas temáticas tratadas pelo conservacionismo clássico, formando o socioambientalismo. 
suas práticas extrativistas não se adequava ao modelo tradicional de reforma agrária com base em lotes familiares. Suas reivindicações, revestidas de justificativas de cuidado ambiental e com forte repercussão internacional, resultaram na criação da primeira reserva extrativista no Brasil, a Reserva Extrativista do Alto Juruá.

Nesses termos, a chamada reforma agrária dos seringueiros ambientalizou-se. Posteriormente, seringueiros e outros excluídos do modelo desenvolvimentista encontraram na reivindicação de territórios protegidos a possibilidade de reprodução de seus modos de vida, que poderiam ser compatibilizados com a conservação da natureza. Desse modo, o socioambientalismo, forjado nesse contexto histórico, define-se como uma concepção que defende o envolvimento das populações locais nas políticas ambientais, levando em consideração seu modo de vida e conhecimentos sobre o manejo dos recursos naturais.

A incorporação de uma agenda social nas políticas de conservação da natureza e a possibilidade de existência de áreas protegidas com gente, que mais tarde foram nomeadas como reservas de uso sustentável, causaram grande insatisfação entre os conservacionistas. As discordâncias relacionavam-se não apenas à descrença a respeito da possibilidade de conciliação entre conservação da natureza e presença humana, mas também às novas orientações participativas, que substituíram justificações técnico-científicas, comandadas pela burocracia estatal, por argumentos morais sobre o cuidado com a natureza, elaborados pelos potenciais implicados nas questões. ${ }^{9}$

Essas disputas entre conservacionistas e socioambientalistas ganharam visibilidade ao longo de oito anos de debates para a elaboração da Lei no 9.985/2000 -Sistema Nacional de Unidades de

9 Conforme já apontamos e descreveremos ao longo do texto, as práticas conservacionistas adquiriram conotações socialmente excludentes. Contudo, a definição de conservação encontrada em documentos da IUCN e outros, além do próprio SNUC, definem a conservação como o manejo do uso humano da natureza, compreendendo a preservação, a manutenção, a utilização sustentável, a restauração e a recuperação do ambiente natural. Nesse sentido, autores orientados por uma perspectiva socioambiental têm utilizado o termo etnoconservação (Diegues, 2000) ou conservação socioambiental (Teisserenc e Sant'Ana Júnior, 2016) para pensar uma ciência e uma prática que surjam das necessidades dos grupos humanos envolvidos. 
Conservação (SNUC) -, entre 1992 e 2000. A reconstituição desse processo permite identificar não apenas um debate específico sobre áreas protegidas, mas um debate sobre modelos de desenvolvimento para a sociedade brasileira, de projetos de nação e cidadania, nos quais a gestão dos recursos naturais assume papel relevante.

Nesse sentido, a lei do SNUC é considerada híbrida porque abriga as tensões entre esses dois modelos polares. Se, por um lado, ela foi fruto do processo de mobilização popular junto a ambientalistas ${ }^{10}$ no contexto de redemocratização da sociedade brasileira no final dos anos 1980, de outro, ela assegurou juridicamente os valores conservacionistas fortalecidos a partir de um conjunto de justificações técnico-científicas apoiadas sobre o discurso de conservação da biodiversidade, que ganharam força durante o período dos regimes autoritários no país (Esterci e Fernandez, 2009; Fernandez, 2014).

O fato é que os debates produzidos em torno da elaboração do SNUC possibilitaram a explicitação das contradições sociais produzidas pelas políticas de conservação da natureza e, pari passu, pelo modelo vigente de desenvolvimento brasileiro. Esse período marca também a oficialização de uma agenda social - orientada aos direitos culturais e territoriais de populações nomeadas como tradicionais - nas políticas de conservação da natureza. De acordo com Montero (2012), a questão ambiental torna-se, assim, uma categoria mediadora na organização de alguns pleitos identitários que fragilizam o modelo clássico de integração em uma base nacional homogênea.

\section{O projeto rumo aos campos: dos sertões com parques aos sertões nos parques}

Tão logo foram realizadas as primeiras experiências com parques nos Estados Unidos, em meados do século XIX, o debate sobre a criação de parques nacionais já se fazia presente no Brasil. Em 1876, o engenheiro e abolicionista André Rebouças publicou um

10 Juliana Santilli (2005) traz detalhada descrição dos debates realizados nessa arena pública, relacionando-os às novas orientações da Constituição e legislações infraconstitucionais que colocaram a conservação da natureza e da sociodiversidade em condições de igualdade. 
artigo, sob o título Parque Nacional, no qual defendia a criação de parques nas “ilhas do Araguaia e do Paraná" (Urban, 1998, p. 82). É preciso lembrar também que, um pouco antes, em 1861, ${ }^{11}$ foi feito o reflorestamento das serras do Maciço da Tijuca, na cidade do Rio de Janeiro, transformando uma parcela deste em Floresta da Tijuca, a partir de um decreto de D. Pedro II. Ainda que oficialmente esse território só tenha sido denominado como parque em 1961, no ato de sua criação, no século XIX, já se faziam presentes uma série de justificativas que compõem o imaginário conservacionista (Esterci e Fernandez, 2009; Fernandez, 2010).

No entanto, foi apenas nos anos 1930 que foram criados os primeiros parques nacionais (Itatiaia, em 1937, e Serra dos Órgãos e Iguaçu, ambos em 1939) e foi a partir dessa década que se constituiu o primeiro conjunto de leis brasileiras relacionadas à proteção da natureza - o Código Florestal, o Código de Caça e Pesca, o Código de Águas, o Código de Minas e o Código de Fiscalização das Expedições Artísticas e Científicas -, todas elas geradas entre maio de 1933 e outubro de 1934.

Franco e Drummond (2005) atribuem essas conquistas legais ao empenho de uma geração de intelectuais atuantes em sociedades civis e instituições científicas do Rio de Janeiro, tais como o Museu Nacional e o Jardim Botânico, entre as décadas de 1920 e 1940, que souberam conectar suas preocupações com a proteção da natureza com o tema da identidade nacional. As imagens e representações associadas aos parques encontraram terreno fértil no discurso sobre modernização do país. Nesse período de intenso nacionalismo, a preocupação com a degradação da natureza fazia parte de uma reflexão sobre a construção de um projeto nacional. Destacam os autores que, nessa fase, outros temas, tais como a saúde, a educação, o trabalho, a indústria, a cultura e o patrimônio histórico, também foram alvo de intensos debates e reformas políticas.

11 Embora nessa data seja criada oficialmente a Floresta da Tijuca e das Paineiras, uma série de estudos, de medidas de desapropriação e de ações de replantio é tomada desde 1844 (Drummond, 1988, p. 287). 
No que diz respeito ao debate específico sobre natureza e projeto nacional, é preciso destacar a influência do pensamento de Alberto Torres (1865-1917) sobre essa geração de intelectuais. Político, jornalista e bacharel em Direito, produziu, em seus textos escritos nos anos de 1910, importante diagnóstico-denúncia (Pádua, 1987) sobre os prejuízos sociais e ambientais causados pelo modelo de desenvolvimento de raízes colônias que se estabeleceu no Brasil e que se perpetuava por meio do que ele definia como "imperialismo contemporâneo”. Este modelo seria responsável pela destruição dos nossos recursos naturais, pela exploração dos trabalhadores e pelo atraso das nossas organizações. Para Alberto Torres, um novo projeto de nação somente seria possível a partir de uma obra de "arquitetura política", de feições nacionalistas, voltadas para a conservação dos recursos naturais, para a proteção dos trabalhadores rurais e para a massa da população brasileira empobrecida e abandonada. Em outras palavras, o processo civilizacional não se daria de forma espontânea, mas sim pela ação do Estado, empenhado em promover tais reformas (op. cit.).

Desse modo, pode-se considerar que o pensamento de Torres também se insere em um debate sobre a sertanidade, dividido entre uma matriz romântica de valorização da autenticidade brasileira e os ideais iluministas, de promoção do progresso e de crença no papel a ser desempenhado pelos cientistas no desenvolvimento da nação. Sob a influência de suas ideias, importantes debates foram travados a respeito da sociedade brasileira, abordando as condições de saúde do homem do campo, as técnicas rudimentares aplicadas à agricultura e o uso predatório dos recursos naturais, face ao imperativo de conservação da natureza.

Para a geração de intelectuais e cientistas dedicados ao estudo da natureza na década de 1930, a criação de parques nacionais era parte integrante de um projeto de nação, que, conforme definiu 
Alberto Sampaio, ${ }^{12}$ deveria ser capitaneado pelo Estado e voltado para o sertão e rumo aos campos. ${ }^{13}$ Em outras palavras, seria uma proposta de reforma social que, em sintonia com os ideais de Torres, buscasse criar melhores condições para os segmentos mais pobres da sociedade e que majoritariamente ocupavam as áreas rurais do país. Entre outras medidas, propunha: a implantação de programas de saneamento e educação rural, de polícia e assistência judiciária e de povoamento que, tomando como base o homem do campo, deveria adotar medidas, tais como açudagem, pequenas indústrias rurais, crédito agrícola, desenvolvimento adequado da agricultura e da pecuária, combate ao loteamento rural etc. (Fernandez, 2014).

A descrição desse programa de desenvolvimento rural pode ser encontrada em O Sertão Carioca (Corrêa, 1933). Em seus escritos, o autor apontava a agricultura como uma das atividades humanas que mais afetavam o meio ambiente, daí o seu esforço para construir um modelo de sociedade agrícola, baseado em princípios técnicos e adequados ao uso equilibrado dos recursos naturais e ao desenvolvimento desses sertanejos que ele considerava os autênticos brasileiros. Junto a este modelo integrado de sociedade e natureza, Corrêa concebia a existência de áreas protegidas sem qualquer tipo de uso direto; eram os parques nacionais.

Deverão ser criadas reservas naturais integrais, constituídas em domínios nacionais intangíveis, de acordo com o Office International pour la Protection de la Nature em suas legislações, pois o Brasil é um dos seus signatários (Corrêa, 1933, p. 174).

No âmbito das instituições científicas e clubes cívicos, esses intelectuais estavam, portanto, sintonizados com os debates

12 Professor do Museu Nacional, Alberto José Sampaio (1881-1946) foi um dos mais importantes botânicos de sua época. Realizou inúmeras palestras e escritos, nos quais procurava articular seu conhecimento da área de biologia com o projeto de nacionalidade proposto por Alberto Torres. Em 1934, organizou a I Conferência Brasileira de Proteção à Natureza, no Rio de Janeiro (Franco e Drummond, 2005, p. 1035).

13 Sampaio (apud Corrêa, 1933, p. 237). 
internacionais sobre a criação de parques e, no Brasil, eles os incorporaram como elementos relevantes de um projeto nacional rumo aos campos.

Pode-se dizer que parte dos anseios dessa geração de pensadores foi atendida: a natureza tornou-se patrimônio nacional, por meio da criação de parques e da criação de códigos específicos e, na década de 1940, foram criadas as primeiras estruturas burocráticas para a gestão dos recursos naturais. Mas, ao contrário do que projetavam esses primeiros ideólogos, a criação dos parques não foi associada a um projeto de nação preocupado com o uso equilibrado da natureza e tampouco voltado a reverter as desigualdades sociais do país.

$\mathrm{Na}$ contramão de suas expectativas, ganha força a ideologia da industrialização nacional e superação de um modelo baseado no desenvolvimento agrário. De acordo com Santos (2009), noções tais como "espaço vital" e integração nacional passaram a ser vinculadas a ações e projetos estatais de cunho modernizante, em resposta às dinâmicas internas e a um cenário internacional de guerra. Nesse contexto, salienta o autor, a incorporação de regiões menos conhecidas tornava-se condição sine qua non do desenvolvimento de todo o país.

Desse modo, a intervenção do Estado na economia e no território, nas décadas seguintes, realiza-se em uma escala macrorregional, com a realização de grandes obras de infraestrutura econômica e grande impacto ambiental, tais como hidrelétricas, portos e rodovias, sem nenhuma consideração pelos modos de vida das populações que habitavam esses espaços.

Retomando, portanto, o debate sobre a sertanidade que mobilizou gerações de pensadores sobre o dilema civilizacional brasileiro - entre um Brasil atlântico, cosmopolita e eurocêntrico e outro autêntico, voltado para a promoção do povo sertanejo -, pode-se dizer que os parques inscreveram-se no primeiro modelo, sobre o eixo de uma modernização excludente. Na verdade, os parques foram tratados como ilhas de conservação, que compensavam ou se ajustavam aos grandes empreendimentos econômicos. Assim, o 
Estado atendia parcialmente às demandas dos cientistas e respondia às exigências crescentes de organismos internacionais preocupados com a defesa do meio ambiente, ao mesmo tempo em que consolidava a marcha de expansão capitalista rumo às regiões Centro-Oeste e Norte entre os anos de 1950 a 1980.

Combinou-se, assim, o não uso da natureza (por meio da criação de áreas protegidas), com o uso destrutivo da natureza fora desses espaços destinados à conservação. Desse modo, é importante destacar que, enquanto as primeiras gerações de cientistas e intelectuais buscavam formas integradas de combinar o não uso da natureza (por meio da criação de áreas protegidas), com o uso equilibrado dos recursos naturais (por meio da defesa de um modelo de desenvolvimento inclusivo e preocupado com a exploração racional dos recursos naturais), o período que se segue se caracterizará justamente pela coexistência entre o não uso e o uso destrutivo da natureza.

A despeito do imaginário conservacionista sobre esses espaços de natureza intocada, parte significativa deles foi criada em territórios ocupados ou manejados por diferentes populações. Quando essa realidade é percebida a partir dos valores consensuais da salvação da natureza, passam despercebidos fatores tais como: a falta de critérios ou de planejamento de gestão para as UCs criadas, o fato de estes territórios já serem ocupados ou de que essas áreas vinham sendo conservadas apesar da permanência de populações humanas. Subitamente elas são postas em uma situação de ilegalidade.

Ainda hoje, essa situação permanece com poucos avanços. $\mathrm{O}$ SNUC prevê como alternativa definitiva a regularização fundiária (leia-se remoção desses grupos). O único instrumento de pactuação, ainda assim temporário, previsto nessa legislação, é a elaboração de termos de compromisso, que, na verdade, são apenas instrumentos administrativos e passíveis de suspensão a qualquer tempo por ambas as partes. 
Embora esses grupos atingidos por UCs de proteção integral vivam em um estado de desterritorialização subjetiva, ${ }^{14}$ cabe enfatizar que são raros os casos de remoção e paradoxalmente a sua permanência em áreas de proteção ambiental tornou-se um trunfo (ainda que frágil) ${ }^{15}$ de salvaguarda de seus territórios.

Assim, pode-se dizer que os sertões resistiram nos parques e, posteriormente, em outras modalidades de UCs definidas como de uso sustentável. De modo não previsto e a contragosto dos idealizadores de áreas protegidas sem gente, as políticas ambientais acabaram por absorver parte importante dos conflitos territoriais e o debate sobre diversidade cultural, étnica e formas de partilha do espaço público.

\section{Os ideários conservacionistas e as políticas de desenvolvimento}

Como se combinaram e se opuseram os ideais conservacionistas e as políticas de desenvolvimento, entre os anos de 1950 até meados de 1980? (Fernandez, 2014). Embora a tecnocracia do governo federal não estivesse sensibilizada por valores de conservação da natureza, apoiava tais iniciativas em função da legitimidade que lhes conferia o discurso científico dominante acionado pelos conservacionistas (Barreto Filho, 2004).

Também, em certo sentido, a criação de áreas protegidas poderia ser compatibilizada com os ideais dos governos militares em assegurar e gerir reservas estratégicas de recursos naturais no território nacional como condição de soberania do país. Há evidências de que esse era um valor igualmente partilhado pelos ideólogos da conservação (Urban, 1998).

A geração de conservacionistas que pôde atuar nos órgãos governamentais, que era herdeira da geração de 1930 e dos escritos

14 De acordo com Sathler (2007), trata-se de um estado de desenraizamento, de desvinculação psicológica dos moradores em relação ao seu lugar, às tradições e ao seu modo de vida. Embora a remoção efetivamente não tenha ocorrido, seu território transformou-se em um espaço de incerteza, em que as regras do que é possível ou não fazer deixaram de ser claras.

15 O ato legal de criação das áreas protegidas não garante sua efetiva implantação nem a proteção de seus limites e recursos naturais. São inúmeras as dificuldades de gestão de UCs no Brasil. 
de Alberto Torres, defendia que o Estado deveria comandar uma intervenção civilizatória de orientação iluminista, na qual a ciência teria papel fundamental. Sugiro que os conservacionistas, apesar de se mostrarem em larga medida desapontados com a atuação do governo na área ambiental, compartilhavam da ideia de controle do território e do planejamento orientado por uma perspectiva tecnocientífica que deveria ser conduzida de modo centralizado pelo poder estatal.

O modo como se constituíram as agências ambientais no Brasil é, para Barreto Filho (2004) e Medeiros (2005), resultado de uma tradição de proteção vinculada à administração florestal, na qual a floresta é vista fundamentalmente como um recurso econômico que deve ser explorado. As iniciativas de proteção à natureza foram, portanto, conduzidas sob essa lógica dominante. Assim, a criação e a gestão dos parques nacionais estiveram historicamente vinculadas ao Ministério da Agricultura. Já em 1967, foi criado o Instituto Brasileiro de Desenvolvimento Florestal (IBDF). Essa instituição foi formada a partir da extinção e fusão do Departamento de Recursos Não Renováveis (DRNR) ${ }^{16}$ do Conselho Florestal, do Instituto Nacional do Pinho e do Instituto Nacional do Mate.

Em 1973, sob o impacto das pressões internacionais para a defesa do meio ambiente a partir da Conferência de Estocolmo e do Clube de Roma, é criada a Secretaria Especial do Meio Ambiente (Sema), no âmbito do Ministério do Interior, passando a dividir com o IBDF a gestão das políticas brasileiras de conservação da natureza. Observa-se, novamente, uma secretaria voltada para a temática ambiental criada em um órgão responsável pela estratégia de desenvolvimento regional.

Em tese, a coexistência de departamentos direcionados a políticas de conservação da natureza (não uso), com departamentos direcionados ao uso, ou à exploração equilibrada dos recursos naturais, deveria estar perfeitamente adequada às orientações das primeiras gerações de pensadores que, desde o fim do século XIX

16 O DRNR foi criado em 1960 em substituição ao antigo Serviço Florestal. 
até meados dos anos 1940, conforme demonstramos anteriormente, preocuparam-se com ambos os temas de forma articulada.

O setor de desenvolvimento florestal visa promover o manejo adequado das florestas para garantir a utilização desse recurso renovável, assegurar a manutenção da indústria florestal e de todos os setores que dependem do uso da madeira, ao mesmo tempo em que cumpre papel importante com relação à conservação, por meio de hortos florestais, da produção de sementes e mudas para reflorestamento de áreas degradadas.

No entanto, não é isso que se deu na prática. Apesar de esses setores coexistir nos mesmos órgãos, havia um completo antagonismo entre suas práticas e valores. Nos setores de desenvolvimento florestal, segundo relatos dos conservacionistas atuantes na época, predominava novamente a lógica da exploração sem limites.

Contudo, é curioso que nos textos produzidos, ao longo de décadas, os participantes do movimento conservacionista, embora atuantes na criação de áreas protegidas, definissem a conservação da natureza como um conjunto amplo de ações envolvendo não apenas a proteção, mas também a preocupação com "maior uso", "melhor uso", "para o número maior de pessoas, de modo permanente". ${ }^{17}$ Confirmando esses valores, Wanderbuilt Duarte de Barros, no final dos anos 1960, em palestra no Clube de Engenharia, deixou claro como o tema da conservação insere-se em uma reflexão abrangente sobre desenvolvimento e como é grande a dificuldade para sensibilizar as autoridades sobre as delicadas relações entre a economia e a ecologia. Ao se apresentar como membro do IBDF, como cidadão brasileiro e como presidente da Fundação Brasileira para a Conservação da Natureza $(\mathrm{FBCN}),{ }^{18}$ destacou que a destruição dos recursos de base é a mais grave ameaça à prosperidade do país:

conservação é uma palavra de sentido econômico, de sentido social, diria mais, de sentido integrativo. [...] conservar quer

17 Citação de Alceo Magnanini (inspirado na definição de Van Hise) em debate com os outros conservacionistas sobre a definição de conservação (Urban, 1998, p. 198).

18 A FBCN foi fundada em 1958 com apoio da IUCN. 
dizer utilizar, da melhor maneira possível, os recursos que podem permitir ao homem as condições finais daquilo que se chama um Estado de bem-estar social. Esta expressão, este sentido ajusta-se integralmente ao conceito de uma das palavras mais discutidas e sobre as quais mais se tem escrito: desenvolvimento. No desempenho das tarefas que temos mantido com diferentes personalidades e autoridades, visando sensibilizá-las para a necessidade de equacionar devidamente a relação conservação-desenvolvimento, estamos surpreendidos com a dificuldade de um diálogo que conduza à frutificação de uma idéia.

[...]

Tem um sentido econômico, mas o sentido econômico nas questões da conservação, tem que estar intimamente vinculado, estribado na base ecológica (Wanderbuilt Duarte de Barros apud Urban, 1998, p. 185; 191).

No entanto, Alceo Magnanini, ${ }^{19}$ um dos conservacionistas mais atuantes nas agências governamentais, critica o fato de se criarem, originalmente, órgãos de conservação da natureza como estruturas burocráticas vinculadas à agricultura, por exemplo, e ressalta a incompatibilidade entre os interesses em jogo: "são duas coisas antagônicas. Agricultura é atividade de quem trabalha o terreno, bota planta, extrai produtos; a conservação da natureza é o contrário" (Fernandez, 2014).

Se, por um lado, sua fala pode estar vinculada ao pessimismo frente às ações incompatíveis com os ideais do conservacionismo postas em prática pelos departamentos de desenvolvimento florestal nas décadas de 1950 a 1980, ele não está se referindo a um tipo especial de agricultura que poderia ser classificada como predatória ou contrária aos interesses da conservação. Refere-se à agricultura em geral como atividade que impacta o meio natural e é contrária às ações de conservação. $\mathrm{O}$ antagonismo desse ponto de vista é, pois, 
entre espaços de livre uso dos recursos naturais e espaços de não uso.

Acreditamos, portanto, que essa dicotomia foi o parâmetro para a atuação do movimento conservacionista brasileiro a partir dos anos de 1950 e contrasta tanto com os ideais das primeiras gerações de intelectuais que refletiram sobre o tema da agricultura quanto com as perspectivas socioambientais recentes que buscam formas de conciliação entre a produção agrícola e a conservação da natureza, por meio de sistemas agroflorestais, orientados, por exemplo, pela ciência da ecologia. De fato, estudos mostram que as práticas agrícolas milenares de povos indígenas e camponeses podem dar contribuição importante para a produção do que hoje define-se como biodiversidade (Santilli, 2009; Diegues, 2002).

Desse modo, é possível sugerir que um dos principais legados da orientação conservacionista para as políticas ambientais no Brasil, foi o não enfrentamento da questão relativa ao uso dos recursos naturais ou da reduzida capacidade dos órgãos ambientais de determinarem os rumos das políticas de desenvolvimento, de modo a levarem em consideração a gestão racional dos recursos.

José Lutzmberger, ambientalista gaúcho, fundador da Associação Gaúcha de Proteção ao Ambiente Natural (Agapan) ${ }^{20}$ e um dos principais atores do movimento ambiental nacional que se constitui no Brasil nos anos 1970 e 1980, assim apresenta o contraste de valores, de estratégias de ação e relacionamento mantidas com o poder público, pelo grupo de conservacionistas (focado na criação de UCs integrais) e as várias correntes da ecologia política ${ }^{21}$ (movimento do qual ele fez parte e que se estabeleceu naquele momento):

20 Segundo Alonso, Costa e Maciel (2007, p. 126), a Agapan também possuía feições conservacionistas e inicialmente era muito parecida com a FBCN, contudo progressivamente diferenciou-se desta nas estratégias de mobilização e formas simbólicas de manifestação, aproximando-se aos poucos do processo de redemocratização.

21 O termo ecologia política é utilizado aqui como uma categoria nativa. Diz respeito à forma como se denominavam os movimentos ambientalistas atuantes no Brasil nas décadas de 1970 e 1980, orientados pela crítica aos modelos de desenvolvimento predatório e por meio da combinação de diferentes agendas de esquerda, que passaram a perceber a desigualdade social na apropriação dos recursos naturais. 
as áreas protegidas são importantes, mas não suficientes. Quando eu estava no governo, um dia, numa reunião de gabinete, os militares botaram um imenso mapa da Amazônia na parede, com um monte de pontinhos verdes: reservas biológicas, parques, estações ecológicas, reservas indígenas, extrativistas. E perguntaram: "o que vocês querem mais? Nós estamos dando tudo isso aqui para vocês!". E eu disse: "vocês acham que essa é a solução? Eu aposto que não. Se isso é a solução, então eu estou assinando que tudo o que está branco neste mapa será destruído" [...].

Ou nós chegamos a uma forma de civilização que viva em harmonia com a natureza e nós não precisaremos de parques, ou então tudo vai ser parque e tudo vai ser sustentável (Lutzemberger apud Urban, 2001, p. 87-88).

Quando nos perguntamos por que os conservacionistas não tiveram um papel mais expressivo em diferentes setores da vida social, restringindo-se à criação de áreas integralmente protegidas, pode-se sugerir que a limitação de atuação desse grupo pode ter sido decorrência do quadro de oportunidades políticas de feições autoritárias, sobre os quais puderam atuar entre os anos 1950 e 1980. De igual maneira, é possível compreender a crítica feita pelos conservacionistas ao modo como funcionavam os órgãos de desenvolvimento florestal implantados no período do nacional-desenvolvimentismo e regidos pela lógica da absoluta exploração econômica e desprovidos de qualquer orientação ecológica. Contudo, há evidências, por meio de suas falas e depoimentos, que para os conservacionistas dessa geração, a preservação da biodiversidade (não uso) por meio de áreas protegidas seria a principal contribuição ou legado para as gerações futuras. A conservacionista Maria Tereza Pádua (Urban, 1998, p. 204) destaca, nesse sentido, o benefício social das UCs, ao garantir a proteção das águas e preservar o banco genético, essencial para as práticas agrícolas. Sugiro que, nesse aspecto do controle e da reserva dos recursos naturais como estratégia de desenvolvimento do país a ser comandada pelo Estado 
por meio de orientação científica, o eixo a partir do qual se fazia possível a produção de consenso ou acordos entre os conservacionistas e a burocracia estatal.

\section{O ponto de vista conservacionista frente ao desenvolvimentismo e ao socioambientalismo}

Em março de 1997, durante o período de tramitação do projeto de lei do SNUC, realizou-se encontro dos chamados conservacionistas históricos ${ }^{22}$ - que tiveram papel relevante na construção de políticas e agências ambientais no Brasil - e que resultou no livro Saudade do Matão (Urban, 1998). Trata-se de um importante registro de suas memórias e balanço de sua atuação, já que, nessa ocasião, puderam confrontar seus valores e iniciativas, dialogando com as novas orientações socioambientais já vigentes na sociedade brasileira. Ao confrontar seus textos das décadas entre 1950 e 1980 e depoimentos nos anos 1990, é possível ter uma melhor compreensão sobre a evolução dos sentidos atribuídos ao termo conservação e o posicionamento desses pensadores frente ao modelo de desenvolvimento posto em prática pelos governos militares e, posteriormente, frente às novas configurações democráticas que a temática ambiental assumiu. Nesse contexto, é possível resgatar os elementos que constituem sentimentos de identidade, continuidade e coerência do grupo conservacionista em sua reconstrução de si, para si e para os outros (Pollak, 1992).

A reconstituição da memória conservacionista permite identificar a oposição e a resistência aos ideais de progresso e desenvolvimento, presentes como valores dominantes na sociedade e nas agências estatais em que atuavam e sobre os quais buscaram intervir ou contornar para a criação de UCs e outras medidas voltadas à proteção do ambiente. Embora esses conservacionistas tenham atuado de forma majoritária sobre a criação de áreas protegidas e sejam lembrados por isso, a leitura de textos de Alceo Magnanini, dos anos 1970, permite identificar o contraste entre a noção de

22 Wanderbuilt de Barros, Alceo Magnanini, Aldemar Coimbra Filho, almirante Ibsen de Gusmão Câmara, Paulo Nogueira Neto e Maria Teresa Jorge Pádua. 
conservação e de preservação e a existência de um programa amplo de mudanças de comportamento social e de atuação do Estado, baseado na manutenção e no uso racional de recursos naturais que incluíam aspectos científicos, econômicos, legislativos e educativos, como ele define:

a conservação da natureza e dos recursos naturais nada mais é que o procedimento inteligente adotado pelo homem de repúdio ao esbanjamento de um recurso natural, em quaisquer atividades, procurando obter maiores benefícios para um número cada vez maior de pessoas, perenemente (Magnanini, 1971).

Entretanto, foram as realizações desse grupo, ligadas à defesa de áreas protegidas sem a presença humana, que contribuíram para a construção de um conjunto de valores que hoje associamos ao conservacionismo em oposição ao socioambientalismo. A defesa incondicional de UCs integrais seria para este grupo uma maneira de minimizar - e não solucionar - o processo crescente de degradação humana sobre o planeta, como indicam suas falas.

É um caminho inexorável, não tem mão dupla nem retorno. Pode haver parada... de vez em quando dá uma paradinha e a Maria Tereza cria uma reserva; dá outra paradinha e o Paulo Nogueira Neto inventa a estação ecológica... mas são paradinhas. O rumo é um só (Alceo Magnanini apud Urban, 1998, p. 347).

Há reações muito válidas, necessárias, para salvar alguma coisa, mas é um navio afundando e o pessoal correndo para os botes salva-vidas (Ibsen de Gusmão Câmara apud Urban, 1998, p. 349).

Na nova conjuntura democrática, permanece a insatisfação frente aos rumos que a questão ambiental assume e passa a ser discutida no Brasil. Termos, tais como desenvolvimento sustentável, 
ou a ideia de criação de UCs de uso sustentável, são encarados pelos conservacionistas como medidas ineficazes para enfrentar a questão ambiental.

Atualmente, é muito difícil fazer uma Unidade de Conservação de uso indireto. Existe mais aceitação para as Unidades de Conservação ditas de "uso sustentável", uma reserva extrativista ou coisa deste tipo, que não são verdadeiramente Unidades de Conservação, não vão conservar nada. Há muito mais interesse no indivíduo que está explorando aquela área, do que na própria área. Esse é um exemplo do uso inadequado do termo desenvolvimento sustentável, que está sendo aplicado também em outros setores. Quer dizer uma ideia válida, correta - embora utópica, começa a ser usada como pretexto para uma porção de coisas erradas (Ibsen de Gusmão Câmara apud Urban, 1998, p. 334).

A defesa de UCs de proteção integral ou de uso indireto, desse modo, baseia-se sobre a descrença no ideal de desenvolvimento sustentável ou a incerteza sobre o que isso significa. Também, a percepção do risco iminente de destruição teria sido acionada com um argumento recorrente para justificar processos autoritários de criação de UCs no Brasil, apoiados sobre argumentos científicos ${ }^{23} \mathrm{e}$ sem preocupação com os impactos dessa medida sobre as populações estabelecidas nos territórios transformados em parques.

Nesses termos, não havia a preocupação em escolher uma categoria de proteção compatível com os modos de vida existentes nos territórios destinados à conservação. Em primeiro lugar, pela crença absoluta na eficácia dos espaços mais restritivos em comparação a outras modalidades de uso e, em segundo lugar, pela consciência de

23 Carneiro, Medeiros e Laurent (2008) destacam que o processo decisório que envolve a criação de UCs nem sempre se apoia em estudos científicos, mas sim no acionamento de termos e jargões científicos que adquiriram consenso e legitimidade no campo ambiental e, assim, permitem justificar a tomada de decisão política. Os autores também destacam a ausência dos cientistas sociais nessa fase prévia. Estes são acionados posteriormente ao ato de criação das UCs, quando os conflitos relacionados à permanência humana nesses territórios já estão instalados. 
que, uma vez promulgado o decreto de criação de uma UC do tipo integral, os habitantes desses espaços assumiriam condições muito desiguais de luta por direitos frente ao poder de Império do Estado. As falas a seguir revelam o modus operandi do processo de criação de áreas protegidas de uso indireto.

Quando começaram a usar o termo "parque de papel”, provocaram uma redução ainda maior na ação conservacionista de governo no Terceiro Mundo. Ridicularizou os parques porque, na prática, é diferente: um decreto cria condições para implementar uma área protegida, mesmo que seja em vinte, trinta, quarenta, cinquenta anos (Maria Tereza Jorge Pádua apud Urban, 1998, p. 336).

Também um ex-diretor do Parque Nacional da Tijuca e colunista da revista eletrônica de perfil conservacionista ( $O$ Eco), em artigo sugestivamente denominado Parques e Democracia: uma equação possível? expressa, com certa melancolia, a dificuldade de criação e implantação de parques com o fim da Ditadura.

Foram-se os tempos do regime autoritário das Ditaduras brasileiras em que as Unidades de Conservação eram criadas por decreto emanado do Poder Executivo, que contavam com a concordância servil do Legislativo e a falta de independência do Judiciário. Naquela época, avaliava-se a necessidade da criação de uma UC pelos prismas da conveniência e relevância ambientais. Pesquisado o nicho ecológico a ser protegido, montava-se um processo. [...] O espaço que os afetados pela criação da nova Unidade de Conservação tinham para contestar era exíguo. Também pequena era a necessidade de fazê-lo, já que poucos parques saíram verdadeiramente do papel. Itatiaia, que é o nosso pioneiro, criado na longínqua década de 1930, ainda tem hoje parte de suas terras sob domínio privado. 
[...] tudo foi muito rápido. Enquanto comemorávamos o advento da democracia, descuidamos de pensar na melhor forma de fazê-la funcionar. Até hoje temos dificuldades em inverter a tradicional cultura brasileira de dar precedência ao direito individual sobre o coletivo. Triste para as Unidades de Conservação que são um bem supostamente de todos (Menezes, 2004).

As citações nos remetem ao que Bourdieu (2006, p. 117) define como um ato de magia social, ao impor, por meio da autoridade daquele que enuncia (o Estado), uma nova visão ou divisão social, alterando fronteiras e dinâmicas de ocupação do espaço, mesmo que leve "vinte, trinta, quarenta, cinquenta anos". Há, nesse sentido, um modelo de gestão de áreas protegidas, baseado na aposta do conflito e não da pactuação com as comunidades locais.

Outro aspecto que chama a atenção na última fala éo acionamento dos ideais de universalidade do ambiente - um bem supostamente de todos -, quando, na verdade, mascara o fato de que os custos e os benefícios de sua proteção são desigualmente distribuídos e expressam valores e interesses de grupos específicos (Fuks, 2001). Além disso, em muitos casos, não se trata de direitos individuais versus coletivos, mas de direitos igualmente coletivos - tais como direitos culturais e territoriais dos diferentes grupos formadores da sociedade brasileira - em confronto com um modelo único e padronizado de conservação da natureza implantado sem nenhum compromisso com o modo de vida das populações locais.

A crescente imposição de valores socioambientais ou ligados aos princípios do desenvolvimento sustentável não apenas foi contestada pelos conservacionistas em seus princípios de coexistência homem-natureza, mas também por ser esta corrente portadora de novos modelos de relação Estado-sociedade, de cidadania e da gestão do território nacional. Paula Montero (2012, p. 94), ao refletir sobre o reconhecimento dos direitos étnicos vinculados à questão ambiental, conclui que o termo desenvolvimento sustentável foi a estratégia discursiva que tornou possível essa articulação. 
Segundo a autora, a novidade desse processo para a imaginação política brasileira deve-se ao fato de que é a "primeira vez [que] o pensamento relativo às diferenças está associado ao problema da construção de instituições democráticas e não do Estado Nacional" (op. cit.).

De fato, desde as primeiras décadas do século XX, sob a perspectiva de diversas gerações de intelectuais, os problemas de nossa identidade e de nosso processo civilizatório eram problemas a serem conduzidos pelo Estado, fruto de uma obra de engenharia política, de um projeto iluminista a ser comandado por especialistas.

O processo de redemocratização da sociedade brasileira na década de 1980 traz novos atores para o cenário político. Nas políticas ambientais, a concepção de um único modelo de conservação da natureza, e de interação homem e natureza, de gestão do território nacional planejado e concebido por especialistas na tecnocracia estatal é contestado pelas diversas formas culturais de apropriação do território e de usos da natureza. A partir de novas estruturas de oportunidades políticas ${ }^{24}$ (Alonso, Costa e Maciel, 2007), os conflitos relacionados aos excluídos do modelo desenvolvimentista rompem aos poucos com a invisibilidade social à qual foram relegados. Quilombolas, faxinalenses, caiçaras, camponeses, seringueiros, entre outros, afirmam novas territorialidades e expressões étnicas e culturais vinculadas a territórios específicos.

$\mathrm{Na}$ Amazônia, essas novas orientações materializam-se no crescimento expressivo de áreas protegidas de uso sustentável. Segundo Verissimo et al. (2011), até 1984, 92\% das áreas de UCs na Amazônia Legal eram do grupo de proteção integral e apenas 8\% de uso sustentável. Essa tendência foi revertida a partir de 1990 e ganhou força, sobretudo em 2002. Já em dezembro de 2011, a proporção era de $64 \%$ da área protegida de uso sustentável, contra 36\% de proteção integral. Quando são consideradas apenas as UCs

24 Os autores referem-se a três EOPs: ao período da Constituinte, da Constituição de 1988 e a Rio-92. Acrescentaríamos o contexto de debates sobre o SNUC para a discussão sobre os direitos culturais e territoriais de populações reunidas em torno da categoria populações tradicionais. 
estaduais, o contraste aumenta de $78 \%$ de uso sustentável para $22 \%$ de proteção integral.

O termo populações tradicionais que aparece em vários dispositivos legais brasileiros e assegura direitos diferenciados de cidadania foi gestado no âmbito das políticas ambientais. Segundo Barreto Filho (2006), o termo foi "inventado" pelo conservacionismo internacional já na década de 1970, a partir dos debates sobre zoneamentos ${ }^{25}$ de parques e a tentativa de equacionar a conservação da biodiversidade com o desenvolvimento socioeconômico local. As zonas antropológicas seriam, assim, áreas destinadas às populações com características culturais específicas e entendidas como parte do ecossistema. No Brasil, no entanto, por força do forte imaginário conservacionista e sua influência nas agências governamentais, o tema da permanência das populações humanas só aparece de forma clara na agenda de discussão dos órgãos gestores em 1992, no projeto de lei para elaboração do SNUC. O histórico da tramitação dessa lei começa em 1988, quando o extinto IBDF encomendou à Fundação Pró-Natureza, dirigida por Maria Tereza Jorge Pádua, uma proposta de lei que instituísse um Sistema Nacional de Unidades de Conservação. Aprovada pelo Conselho Nacional de Meio Ambiente (Conama), a proposta foi então encaminhada ao Congresso Nacional em 1992. Voltado para a defesa exclusiva do valor das espécies e dos ecossistemas, o documento não fazia nenhuma referência ou demonstrava preocupação com os prováveis prejuízos trazidos à vida das populações locais.

Reagindo a esse modelo, os defensores de uma visão socioambiental afirmavam que as UCs de proteção integral existiam em número suficiente e que muitas delas haviam sido criadas de forma autoritária (Sant’Anna, 2003), sem levar em consideração as formas de vida das populações locais. Outro argumento importante questionava a adequação de modelos de preservação transpostos dos

25 Em 1972, no II Congresso Mundial sobre parques e áreas protegidas em Yellowstone, é criada a figura zona antropológica. Para se ter uma ideia da diferença sobre o estatuto da permanência humana em UCs de proteção integral no Brasil, ainda hoje, nos planos de manejo, as zonas com presença humana são definidas como áreas de uso conflitante ou de ocupação temporária, dependendo da instância federativa. 
países desenvolvidos para os países em desenvolvimento, como o nosso, conforme pode ser lido na primeira proposta de substitutivo em 1994 pelo então relator na Comissão de Defesa do Consumidor, Meio Ambiente e Minorias, Fábio Feldmann, que fez diversas alterações no texto original:

[...] o projeto, na forma proposta, padece os efeitos de uma concepção envelhecida sobre o significado e o papel das Unidades de Conservação, concepção esta que tende a desconsiderar as condições específicas dos países pobres como o nosso, e que vem sendo paulatinamente revista e atualizada no mundo todo. [...] incorre-se, via de regra, em um equívoco fundamental: as Unidades de Conservação são concebidas e criadas de cima para baixo, como se fossem entidades isoladas, alheias e acima da dinâmica socioeconômica local e regional (Fábio Feldmann apud Santilli, 2005, p. 115).

$\mathrm{Na}$ verdade, criou-se um novo patamar a partir do qual as disputas seriam estabelecidas, pois logo em seguida passou-se a discutir que populações poderiam ser ou não consideradas tradicionais (Diegues, 2002; Santilli, 2005; Carneiro da Cunha e Almeida, 2000; Sant'Anna, 2003).

Finalmente, a definição de populações tradicionais foi vetada como solução para permitir que cada grupo interessado em reivindicar a tradicionalidade fosse avaliado de acordo com suas condições específicas. Os antropólogos Mauro de Almeida e Manuela Carneiro da Cunha (Santilli, 2005, p. 129) salientam que a proposital abrangência do termo não deve ser entendida como uma confusão conceitual, visto que se trata de uma categoria que precisa ser habitada, ou seja, conquistada por meio de meios práticos e simbólicos - uma identidade pública.

Apenas em 2007 é elaborada a Política Nacional de Desenvolvimento Sustentável dos Povos e Comunidades Tradicionais 
$(\mathrm{PNPCT})^{26}$ e finalmente define-se que povos e comunidades tradicionais são:

grupos culturalmente diferenciados e que se reconhecem como tais, que possuem formas próprias de organização social, que ocupam e usam territórios e recursos naturais como condição para sua reprodução cultural, social, religiosa, ancestral e econômica, utilizando conhecimentos, inovações e práticas gerados e transmitidos pela tradição (BRASIL, 2007).

Alguns autores, no entanto, descrevem a relação do Estado com essas populações em áreas protegidas como um poder tutelar (Souza Lima, 1995; Lobão, 2006; Costa, 2008; Esterci e Schweickardt, 2010; Barreto Filho, 2006), que se caracteriza pelo monopólio do Estado em definir qual população (mediante um status diferenciado, tal como o de população tradicional) e em que situações pode permanecer nos espaços ambientalmente protegidos e, ainda, sob condição de seguir determinadas regras para manter esse direito.

Enquanto para os antropólogos o risco de engessamento de identidades legalmente constituídas é uma ameaça à reprodução de territorialidades específicas e à incorporação das diferenças culturais na arena pública brasileira, os conservacionistas, por razões opostas, criticam a atribuição de diferenças que, ao produzirem formas cristalizadas de viver, impedem a construção de um modelo de cidadania com base em uma perspectiva integracionista do processo civilizatório nacional.

E é exigido que os governos assistam todos igualmente; não que o governo extinga, mutile e danifique um patrimônio que afinal é de todos, por causa do interesse pessoal de alguns. E quer-se prejudicar tudo isso por causa de algumas poucas pessoas? É preciso que ali fiquem enclausuradas, intocáveis e estagnadas? Será que não existem outros lugares onde 
essas mesmas pessoas possam morar e viver com dignidade, evoluir e integradas na sociedade brasileira? (Alceo Magnanini, 2010). ${ }^{27}$

As limitações dadas pela juridificação de identidades apontadas tanto pelos conservacionistas quanto pelos antropólogos explicitam as dificuldades que o tema das diferenças impõe às formas de partilha e gerenciamento do espaço político (Montero, 2012). Esse debate não está restrito ao âmbito das Políticas Nacionais de Conservação da Natureza, mas certamente a luta pelo reconhecimento de territórios socioambientais em UCs contribuiu para a consolidação de uma agenda multicultural no país. Montero (op. cit., p. 94), neste sentido, acredita que as conquistas relacionadas aos direitos culturalmente diferenciados só foram possíveis porque, pelas políticas ambientais, mais exatamente de territórios protegidos, foi possível preservar dois dos princípios históricos fundamentais da soberania do Estado brasileiro: "a preservação da integridade do território nacional e a subordinação política das comunidades étnicas ao poder estatal".

Não obstante as conquistas socioambientais alcançadas, não por acaso, em um período de retração dos investimentos econômicos no país entre as décadas de 1980 e 2000, vivemos, nesta primeira década do século XXI, a expansão de um novo desenvolvimentismo $^{28}$ no Brasil, no qual se observa o engendramento de novas estratégias comandadas pelo Estado de reordenamento do espaço e territórios, que, segundo Almeida (2012), são marcadas pelo disciplinamento do comércio de terras, dos recursos florestais e do uso do subsolo. Essa nova fase não corresponde, como era de se supor, a uma simples oscilação entre UCs integralmente protegidas

27 Essa citação foi produzida no contexto de reação de conservacionistas contra o projeto de lei de recategorização de 3\% da Reserva Biológica Praia do Sul, localizada na Ilha Grande (RJ), destinado a equacionar o conflito estabelecido pela permanência humana da comunidade caiçara, em um trecho da Reserva, denominado Praia do Aventureiro.

28 Promovido por um Estado de feições democráticas e descentralizadas e com forte investimento em atividades mineradoras e agropecuárias, e que, contudo, dá continuidade a processos de modernização induzida de "cima" para "baixo" (Santos, 2009, p. 25). 
ou de uso sustentável, mas a uma ameaça generalizada a ambas as modalidades de áreas protegidas. A título de exemplo dessas novas investidas, destacam-se a Medida Provisória no 558, de janeiro de 2012, que reduziu o limite de sete $\mathrm{UCs}^{29}$ na Amazônia para construção de hidrelétricas na bacia do Rio Tapajós, e o decreto de 29 de setembro de 2011, que declara ser de interesse social, para fins de desapropriação, os territórios de quilombos Brejo dos Crioulos (MG), ao mesmo tempo em que disponibiliza seu subsolo para fins de pesquisa, beneficiamento e exploração mineral (op. cit.).

De modo muitíssimo mais sofisticado, o acionamento de um imaginário de proteção da natureza, seja pelo Estado, seja por empresas ou por fundos de investimentos ambientais, é posto em prática para garantir formas diversas de apropriação de terras e recursos naturais, denominado green grabbing (Penna-Firme e Matos, 2015). Isso se dá ao mesmo tempo em que são impostos limites ou a flexibilização dos direitos territoriais de povos e comunidades tradicionais, ${ }^{30}$ muitos deles criados também nesta última década. De acordo com Almeida (2012), está em curso um processo de dessemantização da noção de proteção da natureza, no qual esta passa a significar, na verdade, seu oposto ou o "protecionismo" de terras, subsolo, recursos naturais por parte do Estado e de empresas que podem, a qualquer momento, requisitar estes recursos ou commodities em nome do chamado desenvolvimento sustentável ou da segurança nacional.

\section{Conclusão}

Ao longo deste artigo, procuramos demonstrar como o campo discursivo a respeito da sertanidade e dos rumos de nosso processo

29 Parque Nacional da Amazônia; Parque Nacional dos Campos Amazônicos; Parque Nacional Mapinguari; Floresta Nacional de Itaituba I; Floresta Nacional de Itaituba II; Floresta Nacional do Crepori; Área de Proteção (APA) do Tapajós. As quatro últimas são modalidades de UCs de uso sustentável.

30 Almeida (2012, p. 69) resume esses limites: mineração em terras indígenas, identidades coletivas ilegitimadas, golpes sucessivos contra a Convenção 169, engessamento do Decreto n 6.040, de 7 de fevereiro de 2007 (Política Nacional de Povos e Comunidades Tradicionais), Ação Direta de Inconstitucionalidade (ADI) do Decreto n 4.887, de novembro de 2003 (regulamenta o procedimento para identificação, reconhecimento, delimitação, demarcação e titulação das terras ocupadas por remanescentes das comunidades dos quilombos). 
civilizatório também se expressa no campo ambiental. Pensar que muitos sertões foram transformados em parques - áreas protegidas que, de acordo com a legislação, não admitem a permanência humana - significa que as justificativas para a proteção da natureza ignoraram os modos de vida, formas culturais diferenciadas de apropriação dos recursos naturais nas diversas regiões e territórios brasileiros. Seus espaços de vida foram tomados como espaços vazios de relações e, portanto, disponíveis a novas formas de divisão social (Bourdieu, 2006).

A invisibilidade a que esses grupos foram relegados pelo modelo vigente de desenvolvimento econômico reproduziu-se também no campo ambiental. Foram, neste sentido, duplamente atingidos: pelos processos de expansão das relações de produção capitalista e também pelas políticas restritivas de conservação da natureza.

A despeito dos ideais dos conservacionistas desde as primeiras décadas deste século, de construção de um modelo de desenvolvimento com o uso racional dos recursos naturais e orientado à promoção dos contingentes mais pobres e abandonados da população brasileira, o legado conservacionista - por meio da criação de UCs de proteção integral - não foi capaz de enfrentar o modelo de desenvolvimento dominante. Assim, no Brasil, combinou-se a crença em espaços de não uso da natureza e, fora deles, o uso indiscriminado da natureza. Mais do que combinar, pode-se dizer que a política de criação de espaços protegidos legitimou-se como iniciativa mitigatória e, portanto, complementar aos grandes empreendimentos.

É por isso que, de acordo com a matriz discursiva da sertanidade, defendemos que o projeto conservacionista alinhou-se com o eixo da modernização capitalista, e durante todos esses anos contribuiu para expropriar os pequenos produtores de seus territórios e privá-los do acesso aos recursos naturais eventualmente existentes.

Isso não significa dizer que as realizações conservacionistas foram exatamente aquelas desejadas pelos ideólogos dessa corrente ambiental, mas realizações possíveis no âmbito de governos 
orientados para objetivos de progresso e crescimento econômico e pouquíssima sensibilidade para temas da conservação da natureza. Contudo, considerando a ambivalência entre o cientificismo e o romantismo presente no debate sobre a sertanidade desde as primeiras décadas do século XX, observa-se a permanência da crença dos conservacionistas no papel do Estado em conduzir, de modo centralizado e tecnocrático, nosso processo civilizatório e a defesa de um modelo culturalmente integracionista da sociedade brasileira. $\mathrm{O}$ acesso aos bens naturais, como são os parques, fazia parte desse projeto de patrimonialização da natureza a ser usufruído por todos os brasileiros.

Voltamos, assim, ao sertão formal das políticas de conservação da natureza. Ele existe como resistência dos próprios "sertanejos" às formas de expropriação do modelo de desenvolvimento modernizador capitalista, que contraditoriamente puderam sobreviver em parques e outras modalidades de UCs restritivas e, posteriormente, em UCs de desenvolvimento sustentável. Resultado da contestação de movimentos de trabalhadores extrativistas na Amazônia e posteriormente em outras regiões do Brasil, o socioambientalismo tem afirmado um modelo alternativo de desenvolvimento para o país, que, segundo Almeida (2004), põe em xeque o mercado de terras, o modelo oficial de cadastros rurais e agropecuários e afirma, com base no pluralismo jurídico, novas relações entre Estado e sociedade e rompe com a invisibilidade com que esses grupos foram historicamente submetidos.

Contudo, passadas décadas das novas orientações socioambientais, é limitada a conquista de direitos de populações tradicionais atingidas pela criação de UCs de proteção integral, quando não são ainda criminalizadas ou submetidas a formas tutelares de acesso a direitos. A imposição de regras específicas de comportamento e adequação a identidades específicas como critério de permanência traz novos ingredientes para o sertão formal das políticas de conservação da natureza. 


\section{Referências}

ALONSO, Ângela; COSTA, Valeriano; MACIEL, Débora. O processo de formação da rede de ativismo ambiental no Brasil. In: SEMINÁRIO NACIONAL MOVIMENTOS SOCIAIS, PARTICIPAÇÃO E DEMOCRACIA, 2., 2007, Florianópolis. Anais... Florianópolis: UFSC, 2007. p. 121-143.

ALVES, Patrick Maia Elder. A configuração moderna do sertão. Sociedade e Estado, Brasília, v. 19, n. 2, jul./dez. 2004.

ALMEIDA, Alfredo Wagner Berno. Terras tradicionalmente ocupadas: processos de territorialização e movimentos sociais. Revista Brasileira de Estudos Urbanos e Regionais, v. 6, n. 1, p. 932, 2004.

- Territórios e territorialidades específicas na Amazônia: entre a proteção e o protecionismo. Caderno CRH, Salvador, v. 25, n. 64, p. 63-71, jan./abr. 2012.

AMADO, Janaína. Região, sertão, nação. Estudos Históricos, Rio de Janeiro, v. 8, n. 15, p. 145-151, 1995. Disponível em: <http:// www.nead.gov.br/tmp/encontro/cdrom/gt/6/Maria_Sarita_ Mota.pdf>. Acesso em: 6 jan. 2008.

BARRETO FILHO, Henyo. Notas para uma história social das áreas de proteção integral no Brasil. In: RICARDO, Fany (Org.). Terras Indígenas \& Unidades de Conservação da Natureza: $o$ desafio das sobreposições. São Paulo: Instituto Socioambiental, 2004. Disponível em: <http://www.iieb.org.br/arquivos/artigo_ henyo.pdf $>$. Acesso em: dez. 2006.

. Populações tradicionais: introdução à crítica da ecologia política de uma noção. In: ADAMS, Cristina; MURRIETA, Rui; NEVES, Walter (Orgs.) Sociedades caboclas amazônicas: modernidade e invisibilidade. São Paulo: Annablume, 2006. BOURDIEU, Pierre. O poder simbólico. 9. ed. Rio de Janeiro:

Bertrand Brasil, 2006. 
BRASIL. Decreto n 6.040, de 7 de fevereiro de 2007. Institui a Política Nacional de Desenvolvimento Sustentável dos Povos e Comunidades Tradicionais. Diário Oficial da União, Brasília, 2007.

CARNEIRO, Maria José; MEDEIROS, Carolina; LAURENT, Catherine. Usos das ciências na regulação ambiental: diálogos entre saberes e políticas públicas. In: REUNIÃO BRASILEIRA DE ANTROPOlOGIA, 26., 2008, Porto Seguro. Anais... Porto Seguro: ABA, 2008.

CARNEIRO DA CUNHA, Manoela; ALMEIDA, Mauro

W. Barbosa. Indigenous people, traditional people and conservation in the Amazon. Daedalus, v. 129, n. 2, p. 315-338, 2000.

CORRÊA, Armando Magalhães. O Sertão Carioca. Rio de Janeiro: Imprensa Nacional, 1933.

COSTA, Gustavo Vilela. O aventureiro, Ilha Grande-RJ: uma análise de mudança social. 2008. Tese (Doutorado em Antropologia) - Universidade Federal do Rio de Janeiro, Rio de Janeiro, 2008.

DIEGUES, Antônio Carlos (Org.). Etnoconservação: novos rumos para a proteção da natureza nos trópicos. 2. ed. São Paulo: USP; Hucitec; Annablume, 2000.

DRUMMOND, José Augusto. O jardim dentro da máquina: breve história ambiental da Floresta da Tijuca. Estudos Históricos, Rio de Janeiro, v. 1, n. 2, p. 276-298, 1988.

. O mito moderno da natureza intocada. São Paulo:

Annablume; Hucitec, 2002.

ESTERCI, Neide; FERNANDEZ, Annelise. O legado conservacionista em questão. Revista Pós Ciências Sociais, v. 6, n. 12, p. 15-40, 2009. 
ESTERCI, Neide; SCHWEICKARDT, Kátia. Territórios amazônicos de reforma agrária e de conservação da natureza. Boletim do Museu Paraense Emílio Goeldi, Belém, v. 5, n. 1, p. 59-77, jan.- abr. 2010.

FERNANDEZ, Annelise Caetano Fraga. Do Sertão Carioca ao Parque Estadual da Pedra Branca: a construção social de uma Unidade de Conservação à luz das políticas ambientais fluminenses e da evolução urbana do Rio de Janeiro. 2009. Tese (Doutorado em Sociologia) - Universidade Federal do Rio de Janeiro, Rio de Janeiro, 2009.

. Um Rio de florestas: uma reflexão sobre o sentido de criação dos parques na cidade do Rio de Janeiro. Estudos Históricos, Rio de Janeiro, v. 24, n. 47, p. 141-161, 2010. . Conservacionismo e políticas de desenvolvimento: o legado dos parques. In: SANT’ANA JÚNIOR, Horácio Antunes; TEISSERENC, Maria José da Silva Aquino; ESTERCI, Neide (Orgs.). Territórios socioambientais em construção na Amazônia brasileira. Rio de Janeiro: 7 Letras, 2014.

FRANCO, José Luiz de Andrade; DRUMMOND, José Augusto. Armando Magalhães Corrêa: gente e natureza de um sertão quase metropolitano. História, Ciências, Saúde - Manguinhos, Rio de Janeiro, v. 12, n. 3, p. 1033-1059, set./dez. 2005. . Proteção à natureza e identidade nacional no Brasil, anos 1920-1940. Rio de janeiro: Fiocruz, 2009.

FUKS, Mário. Conflitos ambientais no Rio de Janeiro: ação e debate nas arenas públicas. Rio de Janeiro: UFRJ, 2001.

LAGO, Antônio; PÁDUA, José Augusto. O que é ecologia. São Paulo: Brasiliense, 1984.

LIMA, Nísia Trindade. Um sertão chamado Brasil. Rio de Janeiro: Iuperj, 1999.

. Euclides da Cunha: o Brasil como sertão. In: BOTELHO, 
Andre; SCHWARTZ, Lilia (Orgs.). Um enigma chamado Brasil. São Paulo: Cia das Letras, 2009.

LOBÃO, Ronaldo Joaquim Silveira. Cosmologias políticas do neocolonialismo: como uma política pública pode se transformar em uma política do ressentimento. 2006. Tese (Doutorado em Sociologia) - Universidade de Brasília, Brasília, 2006.

MAGNANINI, Alceo. Conservação da natureza. A Lavoura, ano 74, p. 2-7, maio/jul. 1971.

. Factoides e fatos. 2. ed. [S.1.]: [s.n.], 2010. Mimeografado. MEDEIROS, Rodrigo. Evolução das tipologias e categorias de áreas protegidas no Brasil. Ambiente e Sociedade, v. 9, n. 1, p. 43-65, jan./jul. 2005.

MENEZES, Pedro da Cunha. Floresta da Tijuca: um resgate do nome imposto pela história. O Eco, 28 out. 2004. Disponível em: <http:// www.oeco.com.br/colunistas>. Acesso em: 2 jan. 2008.

MONTERO, Paula. Multiculturalismo, identidades discursivas e espaço público. Revista Sociologia e Antropologia, v. 2, n. 4, p. 81-101, 2012.

NEVES, Erivaldo Fagundes. O sertão como recorte espacial e como imaginário social. Politéia: história e sociedade, Vitória da Conquista, v. 3, n. 1, p. 153-162, 2003. Disponível em: <http:// www.nead.gov.br/tmp/encontro/cdrom/gt/6/Maria_Sarita_ Mota.pdf>. Acesso em: 6 jan. 2008.

PÁDUA, José Augusto. Natureza e projeto nacional: as origens da ecologia política no Brasil. In: . (Org.). Ecologia e política no Brasil. Rio de Janeiro: Iuperj, 1987.

PENNA-FIRME, Rodrigo; MATOS, Celina. Carvoeiros do passado, quilombolas do futuro? Conflitos e direitos socioambientais de populações residentes no interior do Parque Estadual da Pedra Branca, RJ. In: FERREIRA, Alvaro; RUA, João; MATTOS, Regina Célia (Orgs.). Desafios da 
metropolização do espaço. Rio de Janeiro: Consequência, 2015. POLLAK, Michael. Memória e identidade social. Estudos Históricos, Rio de Janeiro, v. 5, n. 10, p. 200-212, 1992. SANT'ANNA, Renata. Populações humanas em Unidades de Conservação. Boletim Rede Amazônia, ano 2, n. 1, p. 117-123, 2003.

SANTILLI, Juliana. Sociambientalismo e novos direitos: proteção jurídica à diversidade biológica e cultural. São Paulo: Peirópolis, 2005.

. Agrobiodiversidade e direitos dos agricultores. São Paulo: Peiropólis, 2009.

SANTOS, Rodrigo Salles. Estado nacional e desenvolvimento econômico na Amazônia Oriental: modelos de ação estatal e representações da modernização induzida nos últimos 40 anos. In: FERRETI, Sérgio; RAMALHO, José Ricardo (Orgs.). Amazônia: desenvolvimento e meio ambiente e diversidade sociocultural. São Luis: Edufma, 2009.

SARMENTO, Carlos Eduardo. Pelas veredas da capital: Magalhães Corrêa e a invenção formal do Sertão Carioca. Rio de Janeiro: CPDOC, 1998. Disponível em: <www.cpdoc.fgv.br>. Acesso em: 12 abr. 2009.

SATHLER, Evandro B. A “desterritorialização subjetiva” e o "pacto da conservação" na perspectiva de uma geografia socioambiental. Áreas Protegidas e Inclusão Social, Rio de Janeiro, v. 3, n. 1, p. 177-179, 2007.

SIMON, Alba Valéria Santos. Conflitos na conservação: o caso do Parque Estadual da Serra da Tiririca. 2003. Dissertação (Mestrado em Ciência Ambiental) - Universidade Federal 
Fluminense, Rio de Janeiro, 2003.

SOUZA LIMA, Antônio Carlos. Um grande cerco de paz: poder tutelar, indianidade e formação do Estado no Brasil. Petrópolis: Vozes, 1995.

URBAN, Teresa. Saudade do matão: relembrando a história da natureza no Brasil. Curitiba: UFPR, 1998. . Missão quase (im)possivel: aventuras e desventuras do movimento ambientalista no Brasil. São Paulo: Peirópolis, 2001. TEISSERENC, Maria José de Aquino; SANT’ANA JÚNIOR; Horácio Antunes; ESTERCI, Neide (Orgs.). Territórios, mobilizações e conservação socioambiental. São Luís: Edufma, 2016.

VERISSIMO, Adalberto et al. (Orgs.). Expansão de Unidades de Conservação de uso sustentável na Amazônia legal. In: (Orgs.). Áreas protegidas na Amazônia brasileira: avançose desafios. Belém: Imazon; São Paulo: Instituto Socioambiental, 2011.

\section{Resumo}

Este artigo pretende mostrar como a matriz discursiva da sertanidade, ou dos dilemas do processo civilizatório nacional, inaugurada a partir da obra Os Sertões, de Euclides da Cunha, encontra correspondência na política brasileira de conservação da natureza. O embate entre duas correntes ambientais - o conservacionismo e o socioambientalismo -, conformadas ao longo de diferentes conjunturas políticas e jurídico-institucionais, reproduz, no campo ambiental, os dilemas sobre os rumos do projeto civilizacional brasileiro. O texto faz uso de documentos e bibliografia sobre a constituição das políticas de conservação da natureza e sobre os debates acerca de projetos de nação no Brasil.

Palavras-chave: conservadorismo; liberalismo; sociologia; moral; metodologia. 


\section{Abstract}

This paper aims to show how the discursive matrix of sertanidade, or the national civilization process dilemmas, opened from Os Sertões, written by Euclides da Cunha, finds correspondence in Brazilian policy of nature conservation. The disputes between two environmental conceptions: the conservationism and socioenvironmentalism, shaped along different political, legal and institutional situations, reproduce in the environmental field the dilemmas about the direction of the Brazilian civilizational project. The text makes use of documents and literature on the establishment of nature conservation policies and the debate on national projects in Brazil. Keywords: conservatism; liberalism; sociology; moral; methodology.

Recebido em 2 de fevereiro de 2016.

Aprovado em 9 de setembro de 2016. 